\title{
A feedback-based model for CSR assessment and materiality analysis
}

\author{
Calabrese, Armando ; Costa, Roberta; Rosati, Francesco
}

Published in:

Accounting Forum

Link to article, DOI:

10.1016/j.accfor.2015.06.002

Publication date:

2015

Document Version

Peer reviewed version

Link back to DTU Orbit

Citation (APA):

Calabrese, A., Costa, R., \& Rosati, F. (2015). A feedback-based model for CSR assessment and materiality analysis. Accounting Forum, 39(4), 312-327. https://doi.org/10.1016/j.accfor.2015.06.002

\section{General rights}

Copyright and moral rights for the publications made accessible in the public portal are retained by the authors and/or other copyright owners and it is a condition of accessing publications that users recognise and abide by the legal requirements associated with these rights.

- Users may download and print one copy of any publication from the public portal for the purpose of private study or research.

- You may not further distribute the material or use it for any profit-making activity or commercial gain

- You may freely distribute the URL identifying the publication in the public portal

If you believe that this document breaches copyright please contact us providing details, and we will remove access to the work immediately and investigate your claim. 


\title{
A feedback-based model for CSR assessment and materiality analysis
}

\author{
Armando Calabrese ${ }^{1}$, Roberta Costa $^{1}$, Francesco Rosati ${ }^{2}$ \\ ${ }^{1}$ Department of Enterprise Engineering, University of Rome “Tor Vergata”, Italy \\ ${ }^{2}$ DTU Management Engineering, Technical University of Denmark, Denmark
}

* corresponding author: Roberta Costa

Address: University of Rome Tor Vergata, Department of Enterprise Engineering, Via del Politecnico 1, 00133 Rome, Italy.

tel.: +3906 72597799

fax.: +3906 72597951

e-mail: roberta.costa@uniroma2.it 


\title{
A feedback-based model for CSR assessment and materiality analysis
}

\section{Highlights}

1. The model provides the assessment of three aspects of CSR commitment

2. The model profiles customers on the basis of their CSR feedback

3. Customer feedback is assessed basing on CSR expectations and perceptions

4. The model is highly suited for use in CSR evaluation and strategic planning

5. The model provides a valuable instrument for materiality analysis

\begin{abstract}
Current CSR literature offers little insight into how to engage customers and other stakeholders about their CSR expectations and perceptions. The aim of this paper is to propose a model for CSR evaluation and planning based on the classification of customer CSR feedback through the comparison of three aspects of CSR commitment (disclosed, perceived and expected). Although the paper is focused on customers, the model can be applied indifferently to any stakeholder group, thus providing a valuable instrument for materiality analysis and stakeholder engagement. In effect, the model allows identifying material CSR issues regarding all stakeholder perceptions and expectations.
\end{abstract}

Keywords: Corporate Social Responsibility (CSR); CSR expectations and perceptions; Global Reporting Initiative (GRI); materiality analysis; Sustainability Report; stakeholder engagement. 


\section{Introduction}

In recent decades there has been increasing attention to the social and environmental impacts of business, particularly as regards multinational companies. Stakeholders are ever more concerned and responsible about environmental and social issues (Brunk \& Blümelhuber, 2011), and linked to this, customers' purchasing decisions can be related to their awareness of company CSR (Corporate Social Responsibility) activities (Lee \& Shin, 2010; Wigley, 2008; Mohr \& Webb, 2005; David, Kline, \& Dai, 2005). In order to establish a long-lasting relationship with their stakeholders in general and customers in particular, companies need to consider and manage their increasing awareness and concerns, aligning business activities accordingly (Lee \& Shin, 2010).

For these reasons, companies are called on to improve their CSR through appropriate actions regarding social, environmental and economic sustainability (European Commission, 2011; Kolk \& Van Tulder, 2010) and through avoidance of “corporate social irresponsibility” (CSI) (Lin-Hi \& Müller, 2013). At the same time, in order to gain returns from their CSR (such as company reputation, customer loyalty and customer-company identification), companies must then continuously communicate their commitment and true efforts (Schmeltz, 2012; Du, Bhattacharya, \& Sen, 2010; Nielsen \& Thomsen, 2007; Morsing \& Schultz, 2006). For this reason, growing numbers of companies now report to stakeholders on their CSR commitment by means of sustainability reports, websites and other CSR communication activities (Kolk \& Pinkse, 2010; Capriotti \& Moreno, 2007; Perrini, 2005; Pollach, 2003).

However, companies should disclose their CSR effectively, otherwise customers and other stakeholders might not perceive that the company is honest and transparent about its CSR efforts (Castaldo, Perrini, Misani, \& Tencati, 2009; Weber, 2008; Peterson, 2004). Thus to increase stakeholders' CSR perception, companies must improve the effectiveness of their communication, and at the same time they must also make efforts to satisfy the stakeholders' 


\section{CSR expectations.}

In this paper, we focus on customers, considering the distinct aspects of customer perceptions and expectations of CSR as two forms of feedback that companies can use to develop effective CSR. In fact, customer CSR perceptions and expectations provide direct feedback because of their influence on purchase intentions, customer loyalty, company image and reputation and customer-company identification. The actual customer feedback depends on the distance between the beliefs, values and lifestyles of the customers and their perception of the company CSR (Vitell, Ramos, \& Nishihara, 2010; Sen \& Bhattacharya, 2001). Consequently, the same company can receive different and even contrasting CSR feedback based on the multiplicity of its customers' perceptions and expectations (Öberseder, Schlegelmilch, \& Gruber, 2011; Mohr \& Webb, 2005; Mohr, Webb, \& Harris, 2001).

From this, in order to elaborate appropriate CSR initiatives, companies need to organise and classify customer feedback. The classification of CSR feedback requires consideration of three aspects of CSR commitment: i) the CSR commitment disclosed by the company in its sustainability report and website; ii) the CSR commitment perceived by the company customers; iii) the CSR commitment that customers expect or demand from the company.

The literature offers many approaches to the measurement of company-disclosed CSR commitments (Rahman \& Post, 2012; Font, Walmsley, Cogotti, McCombes, \& Häusler, 2012; Bouten et al., 2011; Striukova, Unerman, \& Guthrie, 2008; Beattie \& Thomson, 2007; Guthrie \& Abeysekera, 2006; Longo, Mura, \& Bonoli, 2005). There are also numerous studies dealing with customer-perceived CSR (Pomering \& Dolnicar, 2009; Ramasamy \& Yeung, 2009; Luo \& Bhattacharya, 2006; Becker-Olsen, Cudmore, \& Hill, 2006; Meijer \& Schuyt, 2005) and customer-required CSR (Adlwarth, 2010; Poolthong \& Mandhachitara, 2009; Podnar \& Golob, 2007; Dawkins \& Lewis, 2003).

Following this lead, this paper aims to answer the following research question: "How can 
customer CSR feedback improve the effectiveness of a company's CSR?”. The research question is broken down into the following three sub-questions: 1) How can the disclosure of a company's CSR commitment be assessed? 2) How can the customer expectations and perceptions of a company’s CSR commitment be assessed? 3) How can customer CSR feedback be classified for company benefit?

The general research question and three sub-questions have both academic and practical implications. On the academic side, to the authors' knowledge, the literature does not provide methods for the simultaneous and systematic assessment of these three fundamental aspects of CSR commitment (company-disclosed, customer-required and customer-perceived). On the practical side, the research questions will be answered by developing a model based on customers' expectations and perceptions of the company CSR, which permits the company to monitor and account for the efficiency and effectiveness of its CSR initiatives. The proposed model represents an innovative and useful tool both for assessing ex-post CSR initiatives and for developing future CSR strategies on the basis of a practical classification of customer CSR feedback.

From an accountability perspective, even though the paper is focused on customers, the model can be applied indifferently to any stakeholder group (e.g. suppliers, employees, shareholders, etc.), providing a valuable instrument for materiality analysis. Namely, the method can be employed to identify "material" aspects of CSR, that impact on a company ability to create, preserve or dissipate economic, environmental and social value for itself and its stakeholders (GRI, 2011).

\section{Literature review}

The concept of CSR has expanded rapidly in recent decades, attracting attention from customers, stakeholders, research communities, governments, and companies. The European 
Commission defines CSR as "the responsibility of enterprises for their impacts on society" (European Commission, 2011, p. 6) and "a concept whereby companies integrate social and environmental concerns in their business operations and in their interaction with their stakeholders on a voluntary basis” (European Commission, 2001, p. 8).

\subsection{Relationships between CSR and customer feedback}

Today CSR is no longer limited to strictly philanthropic motivations and actions, but instead involves increasingly important managerial decisions in areas of economic, social and environmental aims (Harwood, Humby, \& Harwood, 2011; Carroll \& Shabana, 2010; Weber, 2008; Porter \& Kramer, 2006). Stakeholders are increasingly interested and involved in environmental and social issues (Lee, Park, Rapert, \& Newman, 2012; Sprinkle \& Maines, 2010; Heslin \& Ochoa, 2008) and prefer to deal with companies that conform to their personal values and beliefs (Vitell, Ramos, \& Nishihara, 2010; Tencati \& Zsolnai, 2009; Vanhamme \& Grobben, 2009). Moreover, CSR research shows that stakeholder perceptions of a company's CSR commitment are positively related to company image and reputation and to capacities to attract, retain and motivate employees (Castaldo et al., 2009; Weber, 2008; Peterson, 2004; Greening \& Turban, 2000). For these reasons, several studies suggest that it may be productive for companies to integrate social and environmental concerns in their core strategy and business operations (Belu \& Manescu, 2012; Sprinkle \& Maines, 2010; Martinuzzi, Gisch-Boie, \& Wiman, 2010; Lin, Yang, \& Liou, 2009; Shen \& Chang, 2009).

Nevertheless, shareholders push top management to achieve CSR profitability targets, inducing organizations to develop only those CSR policies consistent with cost-effective corporate behaviour (Maon, Lindgreen, \& Swaen, 2010, 2009; Berger, Cunningham, \& Drumwright, 2007; Mirvis \& Googins, 2006). Managers can actually behave in a socially irresponsible manner, considering only their own interests and the prime aim of maximisation of shareholder value, without considering other stakeholder interests. In this regard, 
Armstrong (1977) suggests that a shareholder orientation encourages CSI, while a stakeholder orientation reduces it (Freeman, 1984).

Company conduct is often characterised by a complex mix between CSR and CSI (Del Bosco \& Misani, 2011), which can vary according to stakeholder demands and market needs (Armstrong \& Green, 2013). In this regard, Kotchen \& Moon (2012) argue that firms will engage in CSR activities in proportion to their level of CSI activities, thus compensating for CSI to avoid being labelled as socially irresponsible. This happens in all business areas, and particularly in controversial sectors such as tobacco, alcohol, gambling and petroleum (Kolk \& Levy, 2001), where socially irresponsible conduct can draw strong media attention. In these areas, the CSR/CSI balance may represent opportunistic behaviour, involving attempts to hide bad conduct (Cai, Jo, \& Pan, 2011; Hemingway \& Maclagan, 2004) and to exploit CSR as a protective facade in case of hostile events, thus contributing to shareholder welfare (Bansal \& Clelland, 2004).

However, the irresponsible conduct of companies does not go unnoticed by customers and other stakeholders, because they have become much more sceptical and demanding about company CSR activities (Kim \& Lee, 2009; Pomering \& Johnson, 2009; Mohr et al., 2001). Customers prefer to select the companies that truly conform to their values and beliefs (Lee et al., 2012; Vanhamme \& Grobben, 2009), namely those that demonstrate real concern for environmental and social problems. Moreover, socially responsible customers further punish those companies which present themselves as responsible, when these are publicly judged as socially irresponsible (Stokes, 2012; Lange \& Washburn, 2012; Kotchen \& Moon, 2012).

Therefore, if company CSR activities and policies do not fit with customer values, beliefs and expectations, their positive effect could be lessened (Becker-Olsen et al., 2006; Greening \& Turban, 2000; Peterson, 2004). For a company, it becomes imperative to understand customer feedback to CSR, which is dependent on the alignment that customers perceive between their 
expectations and the company’s CSR conduct (Sen \& Bhattacharya, 2001).

\subsection{Materiality analysis in CSR reporting}

Companies must develop and maintain a match between their own values and those of their key stakeholders (GRI, 2011), yet current CSR literature offers little insight into how the companies can actually engage customers and other stakeholders regarding their CSR expectations and perceptions. To improve the quality and enhance the credibility of their CSR disclosure, companies must work hard to listen to feedback from customers and other stakeholders (CSR expectations and perceptions), as well as collaborating with them to obtain deeper insights and mutual benefits (Boesso \& Kumar, 2009). The GRI highlights the importance of providing material reports covering topics and indicators that reflect the organization's significant economic, environmental, and social impacts and/or "that would substantively influence the assessments and decisions of stakeholders” (GRI, 2011, p. 8).

The most serious problem with current CSR reporting is the lack of completeness in covering all the aspects that are material from a stakeholder perspective (e.g. Adams, 2004; de Villiers, C., \& van Staden, 2010; O’Dwyer, Unerman, \& Hession, 2005). Moreover, organizations do not face a homogeneous set of stakeholder expectations and perceptions (Unerman \& Bennett, 2004) and there are no practical tools that offer effective support in identifying and analyzing the various groups of stakeholders (Boesso \& Kumar, 2009). Even though guidelines have been developed to increase companies’ communication and accountability concerning CSR, they are still insufficient to facilitate new accountability relationships, specifically those involving materiality analysis and stakeholder engagement (Moneva, Archel, \& Correa, 2006). The process of stakeholder engagement is necessary for understanding the stakeholder expectations and needs, in order to define report content and the organization's sustainability activities (GRI, 2011). Reports and other forms of CSR disclosure are likely to result as not fully accountable and credible to customers and other stakeholders, unless these are engaged 
in the materiality assessment process. Thus a systematic engagement process is necessary to enhance stakeholder CSR perceptions and to strengthen trust between the organization and its stakeholders, for example in the form of customer-company fit.

\subsection{Research gap}

Practitioners and academics recognise the necessity of specific methods and tools for the systematic assessment of customer-company CSR fit (Lee et al., 2012). However while there have been several empirical studies of the importance of alignment between a company's identity and its CSR initiatives (e.g. Perrini, Russo, \& Tencati, 2007; Becker-Olsen et al., 2006; Menon \& Kahn, 2003), there has been less examination of the question of customercompany CSR fit (e.g. Lee et al., 2012). Most of the studies on customer response to CSR activities do not examine the variables of customer awareness and customer expectations about CSR (Mohr et al., 2001; Pomering \& Dolnicar, 2009). Moreover, some studies focus only on the assessment of specific CSR activities or causes (Sen \& Bhattacharya, 2001; Brown \& Dacin, 1997; Creyer \& Ross, 1996), without providing an overall assessment of the company CSR conduct (Maignan, 2001). Similarly the customer-company CSR fit is also studied only for specific initiatives and not for the overall company CSR conduct.

To respond to the current shortcomings in research and knowledge on how to assess customer-company CSR fit, this paper proposes a CSR model that classifies customers on the basis of their CSR feedback, measuring both their perceptions and expectations. The methodology concerns all CSR practices described by the Global Reporting Initiatives (GRI) guidelines, and is not restricted to specific CSR initiatives.

The approach taken for the CSR model is that of a "customer perspective", aiming at the identification of relevant customers and market segments that are critical to the achievement of companies' CSR strategic goals. This model is also suitable to both measure the efficacy of past CSR initiatives and to formulate future CSR strategies. 


\section{The CSR model}

Companies must interpret and manage the growing customer awareness of CSR and align their businesses accordingly if they wish to exploit CSR-driven opportunities. For this reason, companies must consider CSR feedback (based on customer CSR expectations and perceptions) and compare it to the company reported CSR.

Despite the importance that the literature ascribes to CSR measurement and customercompany alignment, there are as yet no studies that provide methods for the simultaneous and systematic assessment of three important aspects of CSR commitment (company-disclosed, customer-perceived and customer-required). Moreover there is an overall lack of strategic tools to exploit customer feedback regarding CSR.

In order to answer the main research question (How can customer CSR feedback improve the effectiveness of a company's CSR?), we have broken it down into three sub-questions. The answers to the sub-questions lead to the development of a CSR model subdivided in three phases (Figure 1), with each phase of the model addressing one of the sub-questions.

[Figure 1]

The CSR model provides a simultaneous and systematic assessment of the three identified aspects of CSR commitment. Applying the model, we classify customer CSR feedback by means of a position matrix, thus permitting the companies to exploit customer feedback for the identification and development of appropriate CSR initiatives.

The outputs of the first and second phase of the CSR model are three measures (Figure 1):

- “Disclosed Commitment” (DC), meaning the CSR commitment disclosed by means of the company’s sustainability report and website; 
- “Required Commitment” (RC), meaning the CSR commitment that customers require from the company;

- "Perceived Commitment” (PC), meaning the company’s CSR commitment as perceived by its customers.

The output from the third phase of the CSR model is a CSR customer matrix that classifies customers on the basis of their CSR feedback (RC and PC) and the company-reported CSR (DC).

In the subsequent sub-sections we describe each phase of the CSR model.

\subsection{Phase 1: CSR disclosure assessment}

The purpose of the first phase of the CSR model is the assessment of DC, answering to the first sub-research question (How can the disclosure of a company's CSR commitment be assessed?). As indicated in the introduction, companies must continuously disclose their CSR efforts to their customers by means of sustainability reports and websites. Nevertheless, company CSR commitment could be considered inadequate by customers, because of misalignment with their expectations and perceptions. We choose the Global Reporting Initiative’s Sustainability Reporting Guidelines (GRI, 2011) as the basis for assessing DC (also RC and PC), because it is considered one the most complete and best structured frameworks for CSR reporting (Bouten et al., 2011; Farneti \& Guthrie, 2009; Lamberton, 2005). The GRI guidelines are also considered appropriate for all industrial sectors and company dimensions (Alan Willis, 2003). The GRI is subdivided under three sustainability dimensions: economic (EC), environmental (EN) and social, with the social dimension further divided in four sub-dimensions, namely labour practices and decent work (LA), human rights (HR), society (SO) and product responsibility (PR) (GRI, 2011). Given the exhaustive structure of GRI, the proposed model permits analyses of each aspect of the company CSR by means of GRI dimensions, sub-dimensions and indicators. 
From this point onwards we refer to clusters of homogeneous GRI indicators as "CSR items" (Table 1): for example, the GRI indicators LA6, LA7, LA8 and LA9 describe various aspects of the labour health and safety, and they are grouped together in the "occupational Health and Safety” CSR item.

[Table 1]

We apply content analysis in the assessment of company-reported CSR, as this method has previously proven widely effective in the discovery and analysis of patterns in CSR reporting (Bouten et al., 2011; Striukova, Unerman, \& Guthrie, 2008; Beattie \& Thomson, 2007; Guthrie \& Abeysekera, 2006). Content analysis is a research methodology for the standardised evaluation of textual information (Krippendorff, 2004; Neuendorf, 2002; Weber, 1990). To carry out the content analysis we integrate the GRI guidelines in a "tree form" coding structure (Figure 2). The use of the tree approach offers two main advantages: it minimises confusion concerning criteria and reduces disagreement among individual coders (Krippendorff, 2004). The coding tree consists of two layers: i) content and ii) judgments. The “content layer” in turn consists of two levels: i) the GRI dimensions/sub-dimensions and ii) the CSR items. As diagrammed in the content layer, the coders associate elements of the sustainability-report content first to GRI dimensions/sub-dimensions, and then to CSR items. Next, the coders assign a value to each CSR item on a Likert scale from 1 to 5 , based on their judgment of the degree of commitment that sustainability report expresses concerning that particular CSR item.

To reliably measure disclosed commitment (DC) through content analysis, the company sustainability report must be analysed by multiple expert coders, with the coding discrepancies between the coders subject to discussion, reanalysis and reconciliation (Milne \& 
Adler, 1999). The coders' expertise in CSR must be assessed on the basis of their actual work and research experience in the CSR field (i.e. they must be CSR managers and/or researchers).

[Figure 2]

To demonstrate the reliability of the content analysis, agreement among coders (intercoder reliability) must be measured and expressed. Intercoder reliability is "the extent to which independent coders evaluate a characteristic of a message or artefact and reach the same conclusion” (Lombard, Snyder-Duch, \& Bracken, 2002). The measure of intercoder reliability is an essential criterion for validating subjective coding of data in content analysis. Krippendorff's alpha is considered the most suitable index for reporting overall reliability in content analysis (Hayes \& Krippendorff, 2007; Krippendorff, 2004; Lombard et al., 2002; Neuendorf, 2002).

Lombard, Snyder-Duch, \& Bracken (2002) argue that a reliability coefficient equal to or greater than 0.90 should nearly always be considered acceptable, while 0.80 or greater is acceptable in most situations, and 0.70 may be appropriate in some exploratory studies. Lower thresholds can be accepted for indices that are known to be more conservative (e.g. Krippendorff's alpha, Cohen’s kappa and Scott’s pi).

\subsection{Phase 2: Customer CSR expectations and perceptions assessment}

The purpose of the second phase of the CSR model is the assessment of required commitment (RC) and perceived commitment (PC), answering to the second research sub-question (How can the customer expectations and perceptions of a company's CSR commitment be assessed?). RC and PC are two important aspects of customer CSR feedback that can be 
exploited by companies to formulate effective CSR strategies, since the two variables both influence customer purchase intentions, customer loyalty and customer-company identification.

Customer judgments are collected by means of a questionnaire structured to assess, for each CSR item, both the required commitment (RC), and the perceived commitment (PC).

To illustrate the questionnaire structure, we provide the example of the CSR item "customer health and safety” (GRI indicators PR1+PR2):

- Question for assessing RC: “Considering the company under study, what are your expectations of the company CSR commitment regarding the reduction of products and services that impact on health and safety across their life cycle?” The customer must answer using a five-point Likert scale: very low (1); low (2); fair (3); high (4); very high (5).

- Question for assessing PC: “Considering the company under study, what are your perceptions of the company CSR commitment regarding the reduction of products and services that impacts on health and safety across their life cycle?” The customer must answer using the Likert scale.

Similar pairs of questions are formulated for each CSR item defined in Table 1.

The interviewees for administration of the questionnaire must be chosen in a manner that obtains a representative sample of the company customers. The sampling techniques suggested are random sampling, or stratified sampling if data about the composition of the company customers are known. A two stage sampling procedure (store randomly sampled in the first stage and customers randomly sampled in the second stage) is suggested to contain the total number of interviews and costs, given the desired accuracy.

Since the purpose of the proposed CSR model is to classify customers on the basis of CSR feedback, it is important to identify the largest possible number of customer characteristics, 
and in particular customer type (purchase frequency), customer gender, customer education, and age.

\subsection{Phase 3: Customer CSR feedback classification}

The third phase of the CSR model consists of the completion of the CSR customer matrix, with the purpose of answering to the third sub-research question sub-question (How can customer CSR feedback be classified for company benefit?). In this phase we compare the outputs of the previous phases (DC, RC and PC) in order to classify company customers on the basis of their CSR feedback (Figure 3).

\section{[Figure 3]}

It is crucial for the company to understand its customer classification because this then allows it to correct existing CSR initiatives or implement new ones. The model presented permits companies to understand customer feedback regarding their CSR commitment. Companies can analyse the demographic composition (gender, age, education, etc.) of each customer category, thus focusing their investments in CSR and strategically differentiating their CSR efforts. The objective of applying the model is to increase the effectiveness and efficiency of the company's CSR practices, in terms of client involvement and satisfaction of their expectations.

In applying the CSR customer matrix, we can distinguish six typologies of customers: disappointed, sceptical, wooed, caught, deluded and demanding. 


\subsubsection{Disappointed}

Here, the company discloses a degree of CSR commitment (DC) that is lower than customer expectations (RC) (in formula $\mathrm{DC}<\mathrm{RC}$ ), and therefore the CSR efforts reported fail to meet the customer demands. In addition, the value of customer perception (PC) is less than the disclosed commitment (DC) (PC $<\mathrm{DC})$.

Under this aspect of the scenario, either the customer shows no confidence in the transparency of the company sustainability report or is unaware of the full contents of the sustainability report, meaning of the company CSR initiatives. In reality, it can occur that customers are not in any way aware of the existence of the company sustainability report.

In the first case, the customer lack of confidence in the sustainability report can be a consequence of previous CSI conduct (Kotchen \& Moon, 2012), or customers may believe that the real company commitment is lower than the disclosed commitment because the company could tend to magnify the goodness of its CSR conduct for the purposes of the report (Nielsen \& Thomsen, 2007). In the second case, the company has not been able to effectively communicate its true commitment to customers, for example by explaining and emphasising through information campaigns (traditional media, Web, etc.).

For the disappointed customer, $\mathrm{PC}$ is thus definitely lower than $\mathrm{RC}$ ( $\mathrm{PC}<\mathrm{DC}<\mathrm{RC}$ ): the customer does not perceive that the company CSR commitment satisfies her/his expectations. In this overall situation, the customer is disappointed by the company CSR conduct (Mohr et al., 2001). Customer disappointment could create an unfavourable environment for the company, in extreme cases leading to boycotts (Seidman, 2007). When a company fails to meet customer expectations, time and efforts are necessary to regain customer trust and loyalty, company reputation and customer-company alignment (Hong, Yang, \& Rim, 2010; Castaldo et al., 2009; Lamberti \& Lettieri, 2009; Marin, Ruiz, \& Rubio, 2009). If previous CSI conduct has been detected, greater efforts and time are required (Brunk \& Blümelhuber, 
2011). Nonetheless, customer CSR expectations are generally very high and, consequently, the percentage of disappointed customers can be significant, especially in controversial sectors (Cai et al., 2011).

In the case of disappointed customers, CSR initiatives should focus on increasing CSR commitment and on understanding customer beliefs, values, and demands (Vitell, 2003), in order to improve customer-company alignment (Hong et al., 2010; Marin et al., 2009). Companies should also improve communication of CSR efforts, to improve customer perception of the true company CSR commitment (Pomering \& Dolnicar, 2009; Maignan, 2001; Mohr et al., 2001).

\subsubsection{Sceptical}

The disclosed CSR (DC) is greater than or equal to the customer expectations (RC). In this situation ( $\mathrm{DC} \geq \mathrm{RC}$ ), the company-disclosed commitment meets or exceeds customer demands. However, the customer does not perceive the company efforts as satisfactory ( $\mathrm{PC}<\mathrm{RC}$ ), and, consequently, the customer perception (PC) is lower than the reported CSR conduct (DC) $(\mathrm{PC}<\mathrm{DC})$.

In this category ( $\mathrm{PC}<\mathrm{RC} \leq \mathrm{DC})$, the customer is sceptical about the company disclosed CSR commitment or towards CSR in general (Kim \& Lee, 2009; Pomering \& Johnson, 2009; Forehand \& Grier, 2003). The scepticism about company CSR efforts could be caused by ineffective CSR communication (Pomering \& Dolnicar, 2009). In contrast, customer scepticism will decrease when the company demonstrates and communicates appropriate CSR efforts in the long run (Mohr \& Webb, 2005).

In order to obtain public recognition for its CSR efforts and to enhance customer-company alignment, the company’s CSR initiatives should focus both on maintaining high commitment and on improving its CSR communication (Lee et al., 2012; Pomering \& Johnson, 2009; 
Vanhamme \& Grobben, 2009).

\subsubsection{Wooed}

As in the sceptical case, the reported CSR conduct (DC) is greater than or equal to customer expectations $(\mathrm{RC})(\mathrm{DC} \geq \mathrm{RC})$ and greater than customer perceptions $(\mathrm{PC})(\mathrm{DC}>\mathrm{PC})$. However, in this case, the customer perceives the company CSR efforts as satisfactory, since she/he perceives CSR (PC) as greater than or equal to expectations (RC) $(\mathrm{RC} \leq \mathrm{PC}<\mathrm{DC})$.

In this situation, the customer is wooed by the company, and feels that the company is socially responsible. Nevertheless, the company's disclosed efforts (DC) are not completely recognised by its customers (Becker-Olsen et al., 2006; Menon \& Kahn, 2003). For this reason, both CSR communication and CSR investments should be managed in a manner to align RC with DC, in order to increase customer CSR awareness and demands (RC) and to be able to generate shared value from the high company CSR disclosed commitment (DC) (Porter \& Kramer, 2011; Pomering \& Johnson, 2009; Porter \& Kramer, 2006).

\subsubsection{Caught}

As in the sceptical and wooed cases, the CSR efforts that the company discloses (DC) are higher than or equal to those that the consumer demands $(\mathrm{RC})(\mathrm{DC} \geq \mathrm{RC})$. Moreover, in this situation the company successfully communicates its CSR practices, and its CSR disclosed commitment (DC) is very much perceived by its customers (PC) $(\mathrm{PC} \geq \mathrm{DC})$. Consequently, the customer perceives the company CSR efforts as satisfactory: her/his perceptions (PC) are greater than or equal to her/his expectations (RC) (PC $\geq \mathrm{RC})$.

In this scenario $(\mathrm{RC} \leq \mathrm{DC} \leq \mathrm{PC})$, the customer is "caught" by the company CSR disclosed commitment. The company invests to gain the long term trust of its customers and obtains public recognition: both company reputation and customer-company identification are very 
good (Peterson, 2004; Hong, Yang, \& Rim, 2010; Castaldo et al., 2009; Marin, Ruiz, \& Rubio, 2009). The company is able to exploit its reputation as a competitive advantage (Becker-Olsen et al., 2006; Menon \& Kahn, 2003; Sen \& Bhattacharya, 2001). The customer is loyal (Vlachos \& Tsamakos, 2011) and proud to be a stakeholder of this socially responsible company (Turban \& Greening, 1997).

CSR initiatives have to retain the company's caught customers. Accordingly, CSR commitment has to be sustained over time in order to avoid customers become either deluded, demanding or disappointed (Becker-Olsen et al., 2006; Freeman, 1994; Pomering \& Dolnicar, 2009).

\subsubsection{Deluded}

As in the disappointed case, the company discloses a CSR commitment (DC) lower than customer expectations (RC) $(\mathrm{DC}<\mathrm{RC})$, failing to meet the customer demands. However, the customer perceptions (PC) are greater than or equal to the disclosed commitment (DC) (PC $\geq \mathrm{DC}$ ). The customer perceptions (PC) are aligned with or exceed their expectations (RC), and the company is recognised as socially responsible $(\mathrm{PC} \geq \mathrm{RC})$.

In this situation ( $\mathrm{DC}<\mathrm{RC} \leq \mathrm{PC}$ ), the customer is deluded about the company CSR conduct. The company either is exploiting the effect of a past CSR reputation or is benefitting from customer cognitive bias.

The overestimation of the company commitment is temporarily positive but in the long term could be damaging to the company image if CSR commitment is not improved (Brunk \& Blümelhuber, 2011). Customers may act in ways that penalise those companies perceived as socially committed but subsequently recognised as not sufficiently responsible (Pomering \& Dolnicar, 2009; Becker-Olsen et al., 2006). CSR initiatives should focus on improving the CSR commitment and the CSR customer-company alignment. 


\subsubsection{Demanding}

As in the deluded case, the company disclosed commitment (DC) is lower than the customer required commitment $(\mathrm{RC})(\mathrm{DC}<\mathrm{RC})$ and the customer perceives a commitment $(\mathrm{PC})$ greater than or equal to the disclosed commitment (DC) ( $\mathrm{PC} \geq \mathrm{DC}$ ). However, in this situation, customer perception (PC) is lower than expectations (RC) (PC $<\mathrm{RC})$.

In this scenario ( $\mathrm{DC} \leq \mathrm{PC}<\mathrm{RC}$ ), the customer is very demanding in terms of CSR conduct. The company is not able to meet the customer CSR requirements and it is not considered as sufficiently responsible (Pomering \& Dolnicar, 2009; Schlossberger, 1994; Freeman, 1994). CSR initiatives should focus on increasing CSR investments for improving the fit between the company CSR commitment and customer expectations, preferences and values (Kotchen \& Moon, 2012).

In both the disappointed case ( $\mathrm{PC}<\mathrm{DC}<\mathrm{RC}$, section 3.3.1) and the demanding case the customer is exigent in terms of CSR conduct. However in the disappointed category the value of customer perception (PC) is less than the disclosed commitment (DC), so the customer is more characterized by a condition of "disappointment about what he/she perceived" than by high levels of "demandingness". The "disappointed" case presents more difficulty to the company in regaining customers' CSR trust, compared to the problem of satisfying customers of the “demanding” category.

\section{An illustrative application to an Italian retail company}

In this section, as a practical illustration, we apply the proposed CSR model to a retail company operating in Italy. Italy is a world leader in the number of companies certified under sustainability standards (Ciliberti, Pontrandolfo, \& Scozzi, 2008). We choose the retail sector because recent studies have revealed the role of CSR as a key factor in the market positioning 
of retail companies (Elg \& Hultman, 2009; Jones, Comfort, \& Hillier 2005). Customers hold retailers responsible for the socially responsible conduct of all the actors in their supply chain (Amaeshi, Osuji, \& Nnodim 2008; Fuchs \& Kalfagianni, 2009), especially if the suppliers are operating in developing countries (Fernie, Sparks, \& McKinnon, 2010, Pedersen \& Andersen, 2006). To be effective in terms of CSR, retail companies need all the firms in their supply chain to act in a socially responsible manner.

In this respect, the retail company chosen as illustrative example carefully evaluates the whole supply chain, in order to ensure compliance to sustainability standards, by means of an interactive CSR management system that controls the whole business network. The retail company operates in Rome (Italy) with nine stores of various dimensions (3 large stores, 3 medium store, 3 small stores) and about 70,000 members. The company considers CSR commitment as a crucial strategic area and is heavily involved in environmental protection, customer satisfaction, and human rights protection. Since 2001, it has published an annual Social Report, initially as information for external stakeholders, but which has now also become a tool for planning and monitoring. In 2008, the retail company renamed this document as a Sustainability Report, to highlight the concept that it not just a social, but also an environmental and economic reporting tool.

In the first phase of the model application, we measured the retail company's disclosed commitment (DC) through the content analysis of the company Sustainability Report. The analysis was performed by four professional researchers, each of whom has been active in the CSR field since at least 2008, including in publishing research.

First, all coders agreed (intercoder reliability 100\%) to eliminate the CSR items deemed not relevant for the DC assessment of the retail company: "effluents and spills" (EN21+EN23+EN25), “security practices” (HR8), “financial assistance received from a government” (EC4), "freedom of association and collective bargaining” (HR5), "public 
policy” (SO5+SO6) and "anti-competitive behaviour" (SO7). Then, the remaining CSR items were assigned judgment values (Table 3) with an overall intercoder reliability of 92.8\%. Both intercoder reliability measures were calculated by means of the Krippendorff's alpha and the ReCal3® tool (Krippendorff, 2004; Freelon, 2010).

In the second phase of the model application, we submitted a questionnaire to the retail company's customers in order to assess "required” and "perceived” CSR commitment (RC and PC). Each questionnaire takes longer than half an hour to be administered, therefore, due to time and resource constraints, it was decided to limit the dimension of the sample by means of a two-stage sampling procedure. In the first stage, we randomly sampled 3 stores (one for each store dimension). In the second stage, we sampled customers, with probability proportional to the store size. For the current illustrative application we submitted a questionnaire to a sample of 189 customers. The sample is described in Table 2, according to four characteristics: customer type (regular or occasional purchase frequency); customer gender; customer education (low, medium, high); and age (under 40, 40 to 60, over 60, corresponding to adult, middle-aged, senior). Each customer expressed a judgment on the CSR items in the economic, environmental and social sustainability dimensions.

[Table 2]

Subsequently, the internal consistency of questionnaires submitted to the company customers was analysed: the Cronbach's alpha scores are acceptable both for the required commitment (RC) and perceived commitment (PC), respectively 96.3\% and 93.5\% (Cronbach et al., 1972). Table 3 shows the values of DC, RC and PC for each CSR item.

[Table 3] 
In the third phase we employed the CSR model to classify the company customers in different types, according to their CSR feedback. In this particular example of applying the model, high percentages of sceptical customers and significant percentages of disappointed customers are detected (Figure 4).

Concerning items in the economic dimension (EC), the results show that, on average, $34.7 \%$ of the retail company customers are sceptical about company CSR efforts, and $30.1 \%$ are “wooed” by the company CSR conduct. "Caught” customers are $14.3 \%$, while $13.0 \%$ are disappointed. The percentages of demanding and deluded customers are very low, respectively $5.0 \%$ and $3.0 \%$.

Concerning the environmental dimension (EN), we observe that there are high percentages of sceptical (24.4\%), disappointed (21.8\%), and demanding (19.5\%) customers, and lower percentages of caught (15.1\%), deluded (10.7\%) and wooed (8.5\%) customers.

The social dimension is expressed by four sub-dimensions: labour practices and decent work (LA), human rights (HR), society (SO) and product responsibility (PR). Results for LA, HR and SO sub-dimensions show high percentages of sceptical customers (between $32.3 \%$ for the SO and 39.6\% for the LA sub-dimensions), and very low percentages of both deluded (5.1\% for LA and 7.7\% for HR) and demanding customers (between 5.9\% of HR and 7.9\% of SO). For these same LA, HR and SO sub-dimensions, the percentages of caught customers are between $16.8 \%$ (SO) and $25.4 \%$ (HR), wooed customers are between $15.4 \%$ (for LA) and 19.8\% (for SO), and disappointed customers are between 6.3\% (HR) and $15.7 \%$ (SO). Compared to these first three sub-dimensions, the results for the PR sub-dimension show lower percentages of sceptical, wooed and disappointed customers (respectively 20.7\%, 10.5\%, $7.0 \%$ ), balanced by greater shares of deluded, caught, and demanding ones (respectively $25.3 \%, 22.0 \%$ and $14.5 \%$ ). 
[Figure 4]

The CSR customer matrix permits a more detailed CSR assessment, through analysis of each GRI dimension and item with respect to both store dimensions (small, medium and large) and customers' characteristics (age, gender, education, purchase frequency). As an example, we propose an analysis of the productive responsibility (PR) sub-dimension (Figure 5) and, a more detailed one of the PR1+PR2 items (customer health and safety) within this PR subdimension (Figure 6).

Analysis of the PR items shows that for this overall sub-dimension, highly educated respondents seem to be more wooed than those of medium and lower education: wooed judgments are $16.4 \%$ among highly educated respondents and respectively $7.9 \%$ and $9.8 \%$ for the medium and lower educated ones. Highly educated respondents are also less deluded: deluded judgments are $20.0 \%$ for highly educated respondents and $29.7 \%$ and $22.5 \%$ from the medium and lower educated (Figure 5).

Concerning the aspect of gender differences, male respondents are on average less sceptical than female ones (male scepticals are 18.3\%, female scepticals are 22.6\%). However, male respondents appear to be more deluded than female ones (male deluded are $28.4 \%$, female deluded are 23.0\%). Senior customers appear more wooed and less deluded than middle-aged and adult ones. The percentages of sceptical customers are on average lower and the percentages of caught ones are on average higher in the case of regular customers of medium retail stores.

[Figure 5] 
To further illustrate the utility of the proposed model in the detailed analysis of individual aspects of CSR, we provide the example of the measurement for PR1+PR2 (customer health and safety, product responsibility sub-dimension) are seen in Figure 6.

In reference to this CSR item, the customers interviewed are generally less sceptical and wooed and more deluded and demanding, compared to the analysis conducted for the overall product responsibility (PR) sub-dimension. This occurs independently of the retail store dimension and of customer characteristics (purchase frequency, age, gender, education). A situation of this type would suggest that the company should focus on the requirements of the demanding customers, to increase their perception of customer health and safety, and in consequence to increase the company’s CSR efforts in terms of product responsibility.

[Figure 6]

As seen from the different analyses in the example presented, the CSR customer matrix permits the company to classify its clients in different categories. This classification then enables the company to identify the clients on whom it is necessary to focus CSR efforts and investments (for example disappointed customers) and for whom it should develop maintenance initiatives (for example caught customers). Application of the model thus permits the company to identify potential weak points in its CSR and to improve the effectiveness and efficiency of its CSR activities.

Improvement in effectiveness of CSR practices derives from profiling the clients belonging to each category. Referring to the illustrative example, Figure 6 shows that the disappointed category is primarily composed of the clients with the characteristics: customer of a small store, occasional, senior, female, and lower-educated. Thus, using this model, if the company wishes to improve customer perception of its CSR actions concerning a category (here, the 
“disappointed”), it can now observe the composition of this category. In this manner the company can focus its CSR investments in terms of commitment and communication, towards the target clients it views as critical.

Improvement in efficiency of CSR practices derives from the company’s greater awareness of its clientele, thus permitting selective CSR investments with respect to the client profiles that it views as critical, and optimisation of returns on such investments.

\section{Accounting implications}

This paper focuses mainly on the opportunity to enhance the effectiveness of companies' CSR initiatives by exploiting customer CSR feedback. The comparison of three aspects of CSR commitment (DC, PC and RC) reveals strengths and weaknesses of past CSR initiatives, affecting customer purchase intentions, customer loyalty and customer-company identification. Also, the model offers a useful tool for the development of future CSR strategies, taking into account customer classification. In the current study we apply our model to the analysis of customer CSR feedback, however the underlying reasoning remains valid for any stakeholder group (suppliers, employees, shareholders, etc.), therefore the model is equally applicable to all types of stakeholders.

From an accountability perspective, one of variables in the CSR model, disclosed commitment (DC), is measured on the basis of the company sustainability report. This means that the model provides a valuable instrument for materiality analysis, because it reveals the gap between reported CSR commitment (DC) and stakeholder needs (RC and PC). The method can be employed to identify material aspects of CSR, which impact on the company’s ability to create, preserve or dissipate economic, environmental and social value for itself and its stakeholders (GRI, 2011). Indeed, the most serious problem with current CSR reporting is the lack of completeness in covering all aspects that are material from a stakeholder 
perspective (e.g. Adams, 2004; de Villiers, C., \& van Staden, 2010; O’Dwyer, Unerman, \& Hession, 2005). The GRI highlights the importance to provide material reports covering topics and indicators that “reflect the organization’s significant economic, environmental, and social impacts" and/or "that would substantively influence the assessments and decisions of stakeholders” (GRI, 2011, p. 8).

In effect, the main objective of the materiality principle is to provide stakeholders with information consistent with their expectations, so that they can assess the company performance (Bouten, et al., 2011; Hsu et al., 2013). Indeed, material reports provide stakeholders with information that will allow them to evaluate the organization's long and short-term social and environmental performance (Bouten et al., 2011; Gray, 2006; MuñozTorres et al., 2012). Organizations face a wide range of topics on which they should report, nevertheless many of the relevant topics and indicators are those that can reasonably be expected to influence the stakeholders' perceptions and decisions (such as concerning the intention to purchase, or development of customer loyalty). The aim of materiality analysis is to identify relevant issues for CSR reporting and prioritize these material issues in accordance with stakeholder needs and expectations (Deegan \& Rankin, 1997; Hsu et al., 2013).

In this regard, the proposed CSR model can support companies in assessing the materiality of CSR aspects and indicators from the viewpoint of the targeted stakeholder groups (e.g. customers), through their classification on the basis of their CSR feedback. For example, when a great percentage of stakeholders are classified as "disappointed", it is likely that the information disclosure will be considered as unsatisfactory in regards to stakeholder expectations $(\mathrm{DC}<\mathrm{RC}$ ) and perceptions $(\mathrm{PC}<\mathrm{DC})$. In this case, a high percentage of concerned stakeholders reveal the probability of failure in the information disclosure of sustainability reporting: either the stakeholders show no confidence in the transparency of the 
company sustainability report or they are unaware of the full contents of the sustainability report, meaning of the company CSR initiatives.

The main advantage of the method is that it allows the deconstruction of CSR into all its components, deepening the materiality analysis of every CSR dimension, sub-dimension, aspect and indicator. Moreover, "stakeholder engagement processes can serve as tools for understanding the reasonable expectations and interests of stakeholders” (GRI, 2011, p. 10). From this perspective, the stakeholder classification enables the company to identify the relevant stakeholders on whom it is necessary to focus its CSR efforts and investments, thus making the CSR model an effective tool for improving stakeholder engagement.

\section{Conclusions}

The fact that national and multinational companies determine strong impacts in society and the environment implies that they must consider the sustainability of their business approaches. In the present scenario, customers and other stakeholders are increasingly responsible and sensible toward environmental and social issues and so take greater account of sustainability concerns in their purchase choices. In order to establish long lasting relationships with their stakeholders in general and their customers in particular, companies must interpret and manage the growing stakeholder awareness and align business activities accordingly. Thus it is important for companies to compare their declared CSR commitment to the degree of CSR efforts that customers (or other stakeholders) perceive and expect from the company.

In spite of this context, and the importance that the literature ascribes to customer-company CSR fit and to materiality analysis, studies in CSR have not provided us with models for the simultaneous and systematic assessment of three important aspects of CSR commitment, 
namely company-declared, customer-perceived and customer-required commitment, nor with a strategic tool for exploiting customer CSR feedback. Since companies are open systems they need to understand customer feedback on their CSR policies: the simultaneous measure of the three aspects of CSR commitment would allow the development of analyses illustrating the current strength of relations between the company and its customers.

In order to organise and to manage the information provided by customer feedback, this paper has proposed a CSR model. Customers are classified in six categories with regard to their feedback to the company CSR commitment (demanding, sceptical, disappointed, wooed, caught, and deluded customers). This customer classification allows companies to implement targeted CSR initiatives and to identify their potential strengths and weaknesses. In addition, it allows companies to analyse the demographics of the customer categories in order to align their CSR strategies with customer stratification, thus improving the effectiveness and efficiency of their CSR activities.

Moreover, even though the paper is focused on customers, the model can be applied indifferently to any stakeholder group. The comparison of three aspects of CSR commitment puts in evidence the gap between reported CSR commitment and stakeholder needs, providing a valuable instrument for materiality analysis. Materiality analysis provides stakeholders with information that will allow them to evaluate the organization's long and short-term social and environmental performance. The proposed CSR model can support companies in assessing the materiality of CSR aspects and indicators from the viewpoint of targeted stakeholder groups (e.g. customers, suppliers, shareholders, etc.), through the stakeholders' classification on the basis of their CSR feedback. Finally, the model encourages companies to develop systematic stakeholder engagement processes as tools for understanding the reasonable expectations and interests of stakeholders for corporate accountability purposes.

Finally, the model offers the further advantages of simplicity in use and interpretation, 
offering useful and practical information to the companies concerned. It is applicable to any context in which companies are committed to CSR and intend to communicate their efforts to customers.

\section{Acknowledgements}

We thank the reviewers and the editor for the constructive comments and suggestions.

\section{References}

Adams, C. A. (2004). The ethical, social and environmental reporting-performance portrayal gap. Accounting. Auditing \& Accountability Journal, 17(5), 731-757.

Adlwarth, W. (2010). Corporate social responsibility-customer expectations and behaviour in the tourism sector. In R. Conrady, M. Buck, \& P. Viehl (Eds.), Trends and Issues in Global Tourism 2010. Berlin-Heidelberg, Germany: Springer: 101-109.

Alan Willis, C. A. (2003). The role of the global reporting initiative's sustainability reporting guidelines in the social screening of investments. Journal of Business Ethics, 43(3), 233237.

Amaeshi, K. M., Osuji, O. K., \& Nnodim, P. (2008). Corporate social responsibility in supply chains of global brands: a boundaryless responsibility? Clarifications, exceptions and implications. Journal of Business Ethics, 81(1), 223-234.

Armstrong, J. S. (1977). Social irresponsibility in management. Journal of Business Research, 5(3), 185-213.

Armstrong, J., \& Green, K. (2013). Effects of corporate social responsibility and irresponsibility policies. Journal of Business Research, 66(10), 1922-1927.

Bansal, P., \& Clelland, I. (2004). Talking trash: legitimacy, impression management, and unsystematic risk in the context of the natural environment. Academy of Management Journal, 47(1), 93-103.

Beattie, V., \& Thomson, S. J. (2007). Lifting the lid on the use of content analysis to investigate intellectual capital disclosures. Accounting Forum, 31(2), 129-163.

Becker-Olsen, K. L., Cudmore, B. A., \& Hill, R. P. (2006). The impact of perceived corporate social responsibility on consumer behavior. Journal of Business Research, 59(1), 46-53.

Belu, C., \& Manescu, C. (2012). Strategic corporate social responsibility and economic performance. Applied Economics, 45(19), 2751-2764.

Berger, I. E., Cunningham, P., \& Drumwright, M. E. (2007). Mainstreaming corporate social responsibility: developing market for virtue. California Management Review, 49(4), 132157.

Boesso, G., \& Kumar, K. (2009). Stakeholder prioritization and reporting: Evidence from Italy and the US. Accounting Forum, 33 (2), 162-175.

Bouten, L., Everaert, P., Van Liedekerke, L., De Moor, L., \& Christiaens, J. (2011). 
Corporate social responsibility reporting: A comprehensive picture?. Accounting Forum, 35(3), 187-204.

Brown, T. J., \& Dacin, P. A. (1997). The company and the product: corporate associations and consumer product responses. The Journal of Marketing, 61(1), 68-84.

Brunk, K. H., \& Blümelhuber, C. (2011). One strike and you're out: Qualitative insights into the formation of consumers' ethical company or brand perceptions. Journal of Business Research, 64(2), 134-141.

Cai, Y., Jo, H., \& Pan, C. (2011). Vice or virtue? The impact of corporate social responsibility on executive compensation. Journal of Business Ethics, 104(2), 159-173.

Capriotti, P., \& Moreno, A. (2007). Corporate citizenship and public relations: The importance and interactivity of social responsibility issues on corporate websites. Public Relations Review, 33(1), 84-91.

Carroll, A. B., \& Shabana, K. M. (2010). The business case for corporate social responsibility: a review of concepts, research and practice. International Journal of Management Reviews, 12(1), 85-105.

Castaldo, S., Perrini, F., Misani, N., \& Tencati, A. (2009). The missing link between corporate social responsibility and consumer trust: The case of fair trade products. Journal of Business Ethics, 84(1), 1-15.

Ciliberti, F., Pontrandolfo, P., \& Scozzi, B. (2008). Investigating corporate social responsibility in supply chains: a SME perspective. Journal of Cleaner Production, 16(15), 1579-1588.

Creyer, E. H., \& Ross Jr, W. T. (1996). The impact of corporate behavior on perceived product value. Marketing Letters, 7(2), 173-185.

Cronbach, L. J. (1972). The dependability of behavioral measurements: Theory of generalizability for scores and profiles. New York, NY: John Wiley \& Sons.

David, P., Kline, S., \& Dai, Y. (2005). Corporate social responsibility practices, corporate identity, and purchase intention: A dual-process model. Journal of Public Relations Research, 17(3), 291-313.

Dawkins, J., \& Lewis, S. (2003). CSR in Stakeholder Expectations: And Their Implication for Company Strategy. Journal of Business Ethics, 44(2-3), 185-193.

de Villiers, C., \& van Staden, C. J. (2010). Shareholders' requirements for corporate environmental disclosures: A cross country comparison. The British Accounting Review, 42(4), 227-240.

Deegan, C., \& Rankin, M. (1997). The materiality of environmental information to users of annual reports. Accounting Auditing \& Accountability Journal, 10(4), 562-583.

Del Bosco, B., \& Misani, N. (2011). Keeping the enemies close: The contribution of corporate social responsibility to reducing crime against the firm. Scandinavian Journal of Management, 27(1), 87-98.

Du, S., Bhattacharya, C. B., \& Sen, S. (2010). Maximizing business returns to corporate social responsibility (CSR): the role of CSR communication. International Journal of Management Reviews, 12(1), 8-19.

Elg, U., \& Hultman, J. (2011). Retailers' management of corporate social responsibility (CSR) in their supplier relationships-does practice follow best practice?. The International Review of Retail, Distribution and Consumer Research, 21(5), 445-460. 
European Commission. (2001). Green Paper: Promoting a European Framework for Corporate Social Responsibility. Brussels: European Commission.

European Commission. (2011). A renewed EU strategy 2011-14 for corporate social responsibility. Bruxelles, Belgium: European Commission.

Farneti, F., \& Guthrie, J. (2009). Sustainability reporting by Australian public sector organisations: why they report. Accounting Forum, 33(2), 89-98.

Fernie, J., Sparks, L., \& McKinnon, A. C. (2010). Retail logistics in the UK: past, present and future. International Journal of Retail \& Distribution Management, 38(11/12), 894-914.

Font, X., Walmsley, A., Cogotti, S., McCombes, L., \& Häusler, N. (2012). Corporate social responsibility: The disclosure-performance gap. Tourism Management, 33(6), 15441553.

Forehand, M. R., \& Grier, S. (2003). When is honesty the best policy? The effect of stated company intent on consumer skepticism. Journal of Consumer Psychology, 13(3), 349356.

Freelon, D. G. (2010). ReCal: Intercoder reliability calculation as a web service. International Journal of Internet Science, 5(1), 20-33.

Freeman, R. E. (1984). Strategic management: A stakeholder approach (Vol. 1). Boston, MA: Pitman.

Freeman, R. E. (1994). The politics of stakeholder theory: Some future directions. Business Ethics Quarterly, 4(4), 409-421.

Fuchs, D., \& Kalfagianni, A. (2009). Discursive power as a source of legitimation in food retail governance. The International Review of Retail, Distribution and Consumer Research, 19(5), 553-570.

Global Reporting Initiative. (2011). G3.1, Sustainability reporting guidelines. Amsterdam, The Netherlands: Global Reporting Initiative. Retrieved from: www.globalreporting.org.

Gray, R. (2006). Social, environmental and sustainability reporting and organisational value creation. Whose value? Whose creation? Accounting, Auditing \& Accountability Journal, 19(6), 793-819.

Greening, D. W., \& Turban, D. B. (2000). Corporate social performance as a competitive advantage in attracting a quality workforce. Business \& Society, 39(3), 254-280.

Guthrie, J., \& Abeysekera, I. (2006). Content analysis of social, environmental reporting: what is new?. Journal of Human Resource Costing \& Accounting, 10(2), 114-126.

Harwood, I., Humby, S., \& Harwood, A. (2011). On the resilience of Corporate Social Responsibility. European Management Journal, 29(4), 283-290.

Hayes, A. F., \& Krippendorff, K. (2007). Answering the call for a standard reliability measure for coding data. Communication Methods and Measures, 1(1), 77-89.

Hemingway, C. A., \& Maclagan, P. W. (2004). Managers' personal values as drivers of corporate social responsibility. Journal of Business Ethics, 50(1), 33-44.

Heslin, P., \& Ochoa, J. (2008). Understanding and developing strategic corporate social responsibility. Organizational Dynamics, 37(2), 125-144.

Hong, S. Y., Yang, S. U., \& Rim, H. (2010). The influence of corporate social responsibility and customer-company identification on publics' dialogic communication intentions. Public Relations Review, 36(2), 196-198.

Hsu, C. W., Lee, W. H., \& Chao, W. C. (2013). Materiality analysis model in sustainability 
reporting: a case study at Lite-On Technology Corporation. Journal of Cleaner Production, 57, 142-151.

Jones, P., Comfort, D., \& Hillier, D. (2005). Corporate social responsibility and the UK's top ten retailers. International Journal of Retail \& Distribution Management, 33(12), 882892.

Kim, Y. J., \& Lee, W. N. (2009). Overcoming consumer skepticism in cause-related marketing: The effects of corporate social responsibility and donation size claim objectivity. Journal of Promotion Management, 15(4), 465-483.

Kolk, A., \& Levy, D. (2001). Winds of change: corporate strategy, climate change and oil multinationals. European Management Journal, 19(5), 501-509.

Kolk, A., \& Pinkse, J. (2010). The integration of corporate governance in corporate social responsibility disclosures. Corporate Social Responsibility and Environmental Management, 17(1), 15-26.

Kolk, A., \& Van Tulder, R. (2010). International business, corporate social responsibility and sustainable development. International Business Review, 19(2), 119-125.

Kotchen, M. J., \& Moon, J. J. (2012). Corporate social responsibility for irresponsibility. The B.E. Journal of Economic Analysis \& Policy, 12(1), 1-23.

Krippendorff, K. (2004). Content analysis, an introduction to its methodology. Thousand Oaks, CA: Sage Publications Inc.

Lamberti, L., \& Lettieri, E. (2009). CSR practices and corporate strategy: Evidence from a longitudinal case study. Journal of Business Ethics, 87(2), 153-168.

Lamberton, G. (2005). Sustainability accounting - a brief history and conceptual framework. Accounting Forum, 29(1), 7-26.

Lange, D., \& Washburn, N. T. (2012). Understanding attributions of corporate social irresponsibility. Academy of Management Review, 37(2), 300-326.

Lee, E. M., Park, S.-Y., Rapert, M. I., \& Newman, C. L. (2012). Does perceived consumer fit matter in corporate social responsibility issues?. Journal of Business Research, 65(11), $1558-1564$.

Lee, K. H., \& Shin, D. (2010). Consumers’ responses to CSR activities: The linkage between increased awareness and purchase intention. Public Relations Review, 36(2), 193-195.

Lin, C. H., Yang, H. L., \& Liou, D. Y. (2009). The impact of corporate social responsibility on financial performance: Evidence from business in Taiwan. Technology in Society, 31(1), 56-63.

Lin-Hi, N., \& Müller, K. (2013). The CSR bottom line: Preventing corporate social irresponsibility. Journal of Business Research, 66(10), 1928-1936.

Lombard, M., Snyder-Duch, J., \& Bracken, C. C. (2002). Content analysis in mass communication: Assessment and reporting of intercoder reliability. Human communication research, 28(4), 587-604.

Longo, M., Mura, M., \& Bonoli, A. (2005). Corporate social responsibility and corporate performance: the case of Italian SMEs. Corporate Governance, 5(4), $28-42$.

Luo, X., \& Bhattacharya, C. B. (2006). Corporate social responsibility, customer satisfaction, and market value. Journal of Marketing, 70(4), 1-18.

Maignan, I. (2001). Consumers' perceptions of corporate social responsibilities: a crosscultural comparison. Journal of Business Ethics, 30(1), 57-72. 
Maon, F., Lindgreen, A., \& Swaen, V. (2009). Designing and implementing corporate social responsibility: a framework grounded in theory and practice. Journal of Business Ethics, 87(1), 71-89.

Maon, F., Lindgreen, A., \& Swaen, V. (2010). Organizational stages and cultural phases: A critical review and a consolidative model of corporate social responsibility development. International Journal of Management Reviews, 12(1), 20-38.

Marin, L., Ruiz, S., \& Rubio, A. (2009). The role of identity salience in the effects of corporate social responsibility on consumer behavior. Journal of Business Ethics, 84(1), 65-78.

Martinuzzi, A., Gisch-Boie, S., \& Wiman, A. (2010). Does corporate responsibility pay off? Exploring the links between CSR and competitiveness in Europe's industrial sectors. Final Report of project ENTR/2008/031, "Responsible Competitiveness" on behalf of the European Commission. Research Institute for Managing Sustainability, Vienna University of Economics and Business, Vienna, Austria.

Meijer, M. M., \& Schuyt, T. (2005). Corporate social performance as a bottom line for consumers. Business \& Society, 44(4), 442-461.

Menon, S., \& Kahn, B. E. (2003). Corporate sponsorships of philanthropic activities: when do they impact perception of sponsor brand?. Journal of Consumer Psychology, 13(3), 316327.

Milne, M. J., \& Adler, R. W. (1999). Exploring the reliability of social and environmental disclosures content analysis. Accounting, Auditing \& Accountability Journal, 12(2), 237256.

Mirvis, P., \& Googins, B. (2006). Stages of corporate citizenship: A developmental framework. California Management Review, 48(2), 104-126.

Mohr, L. A., \& Webb, D. J. (2005). The effects of corporate social responsibility and price on consumer responses. Journal of Consumer Affairs, 39(1), 121-147.

Mohr, L. A., Webb, D. J., \& Harris, K. E. (2001). Do consumers expect companies to be socially responsible? The impact of corporate social responsibility on buying behavior. Journal of Consumer Affairs, 35(1), 45-72.

Moneva, J. M., Archel, P., \& Correa, C. (2006). GRI and the camouflaging of corporate unsustainability. Accounting Forum, 30, 121-137

Morsing, M., \& Schultz, M. (2006). Corporate social responsibility communication: stakeholder information, response and involvement strategies. Business Ethics: A European Review, 15(4), 323-338.

Muñoz-Torres, M. J., Escrig-Olmedo, E., Ferrero-Ferrero, I., Fernandez-Izquierdo, M. A., Leon-Soriano, R., \& Rivera-Lirio, J. M. (2012). Materiality Analysis for CSR Reporting in Spanish SMEs. International Journal of Management, Knowledge and Learning, (2), 231-250.

Neuendorf, K. (2002). The Content Analysis Guidebook. Thousand Oaks, CA: Sage Publications Inc.

Nielsen, A. E., \& Thomsen, C. (2007). Reporting CSR - what and how to say it?. Corporate Communications: An International Journal, 12(1), 25-40.

O’Dwyer, B., Unerman, J., \& Hession, E. (2005). User needs in sustainability reporting: Perspectives of stakeholders in Ireland. European Accounting Review, 14(4), 759-787. 
Öberseder, M., Schlegelmilch, B. B., \& Gruber, V. (2011). "Why don’t consumers care about CSR?”: A qualitative study exploring the role of CSR in consumption decisions. Journal of Business Ethics, 104(4), 449-460.

Pedersen, E. R., \& Andersen, M. (2006). Safeguarding corporate social responsibility (CSR) in global supply chains: how codes of conduct are managed in buyer-supplier relationships. Journal of Public Affairs, 6(3-4), 228-240.

Perrini, F. (2005). Building a European portrait of corporate social responsibility reporting. European Management Journal, 23(6), 611-627.

Perrini, F., Russo, A., \& Tencati, A. (2007). CSR strategies of SMEs and large firms. Evidence from Italy. Journal of Business Ethics, 74(3), 285-300.

Peterson, D. K. (2004). The relationship between perceptions of corporate citizenship and organizational commitment. Business \& Society, 43(3), 296-319.

Podnar, K., \& Golob, U. (2007). CSR expectations: the focus of corporate marketing. Corporate Communications: An International Journal, 12(4), 326-340.

Pollach, I. (2003). Communicating corporate ethics on the World Wide Web: A discourse analysis of selected company Web sites. Business \& Society, 42(2), 277-287.

Pomering, A., \& Dolnicar, S. (2009). Assessing the prerequisite of successful CSR implementation: are consumers aware of CSR initiatives?. Journal of Business Ethics, 85(2), 285-301.

Pomering, A., \& Johnson, L. W. (2009). Advertising corporate social responsibility initiatives to communicate corporate image: Inhibiting scepticism to enhance persuasion. Corporate Communications: an International Journal, 14(4), 420-439.

Poolthong, Y., \& Mandhachitara, R. (2009). Customer expectations of CSR, perceived service quality and brand effect in Thai retail banking. International Journal of Bank Marketing, 27(6), 408-427.

Porter, M. E., \& Kramer, M. R. (2006). Strategy and society: the link between competitive advantage and corporate social responsibility. Harvard Business Review, 84(12), 78-92.

Porter, M. E., \& Kramer, M. R. (2011). Creating shared value: how to reinvent capitalism and unleash a wave of innovation and growth. Harvard Business Review, 89(1-2), 62-77.

Rahman, N., \& Post, C. (2012). Measurement issues in environmental corporate social responsibility (ECSR): Toward a transparent, reliable, and construct valid instrument. Journal of Business Ethics, 105(3), 307-319.

Ramasamy, B., \& Yeung, M. (2009). Chinese consumers' perception of corporate social responsibility (CSR). Journal of Business Ethics, 88(1), 119-132.

Schlossberger, E. (1994). A new model of business: Dual-investor theory. Business Ethics Quarterly, 4(4), 459-474.

Schmeltz, L. (2012). Consumer-oriented CSR communication: focusing on ability or morality?. Corporate Communications: An International Journal, 17(1), $29-49$.

Seidman, G. (2007). Beyond the boycott: Labor rights, human rights, and transnational activism. New York, NY: Russell Sage Foundation Publications.

Sen, S., \& Bhattacharya, C. (2001). Does doing good always lead to doing better? Consumer reactions to corporate social responsibility?. Journal of Marketing Research, 38(2), 225243.

Shen, C. H., \& Chang, Y. (2009). Ambition versus conscience, does corporate social 
responsibility pay off? The application of matching methods. Journal of Business Ethics, 88(1), 133-153.

Sprinkle, G. B., \& Maines, L. A. (2010). The benefits and costs of corporate social responsibility. Business Horizons, 53(5), 445-453.

Stokes, P. (2012). The Janus dialectic of corporate social irresponsibility and corporate social responsibility - the role of micro-moments. Critical Studies on Corporate Responsibility, Governance and Sustainability, 4, 83-108.

Striukova, L., Unerman, J., \& Guthrie, J. (2008). Corporate reporting of intellectual capital: evidence from UK companies. The British Accounting Review, 40(4), 297-313.

Tencati, A., \& Zsolnai, L. (2009). The collaborative enterprise. Journal of Business Ethics, 85(3), 367-376.

Turban, D. B., \& Greening, D. W. (1997). Corporate social performance and organizational attractiveness to prospective employees. Academy of Management Journal, 40(3), 658672.

Unerman, J., \& Bennett, M. (2004). Increased stakeholder dialogue and the internet: towards greater corporate accountability or reinforcing capitalist hegemony? Accounting, Organizations and Society, 29(7), 685-707.

Vanhamme, J., \& Grobben, B. (2009). “Too good to be true!”. The effectiveness of CSR history in countering negative publicity. Journal of Business Ethics, 85(2), 273-283.

Vitell, S. J. (2003). Consumer ethics research: Review, synthesis and suggestions for the future. Journal of Business Ethics, 43(1-2), 33-47.

Vitell, S. J., Ramos, E., \& Nishihara, C. M. (2010). The role of ethics and social responsibility in organizational success: A Spanish perspective. Journal of Business Ethics, 91(4), 467483.

Vlachos, P. A., \& Tsamakos, A. (2011). Corporate social responsibility: attributions, loyalty and the mediating role of trust. Journal of the Academy of Marketing Science, 37(2), $170-180$.

Weber, M. (2008). The business case for corporate social responsibility: A company-level measurement approach for CSR. European Management Journal, 26(4), 247-261.

Weber, R. P. (1990). Basic content analysis (Vol. 49). Thousand Oaks, CA: Sage Publications, Inc.

Wigley, S. (2008). Gauging consumers' responses to CSR activities: Does increased awareness make cents?. Public Relations Review, 34(3), 306-308. 


\section{Figures}

RESEARCH SUB-QUESTIONS

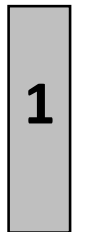

\section{How can the customer} be assessed?
MODEL PHASES

Content analysis of the company's sustainability

report and website expectations and perceptions of a company's CSR commitment

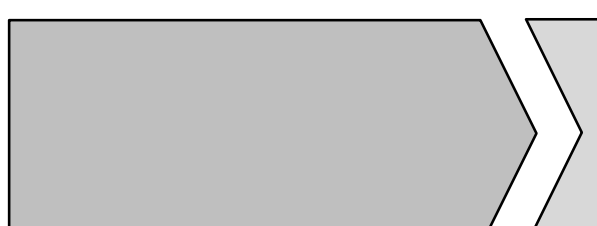

(1)

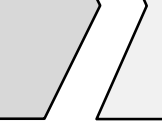

MODEL OUTPUT

Disclosed Commitment

(DC)

Customer data gathering (questionnaire administration)

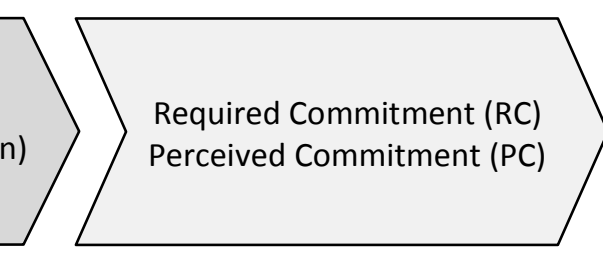

Classification of customer CSR feedback in 6 categories

Figure 1: Research sub-questions linked to the three phases of the CSR model 


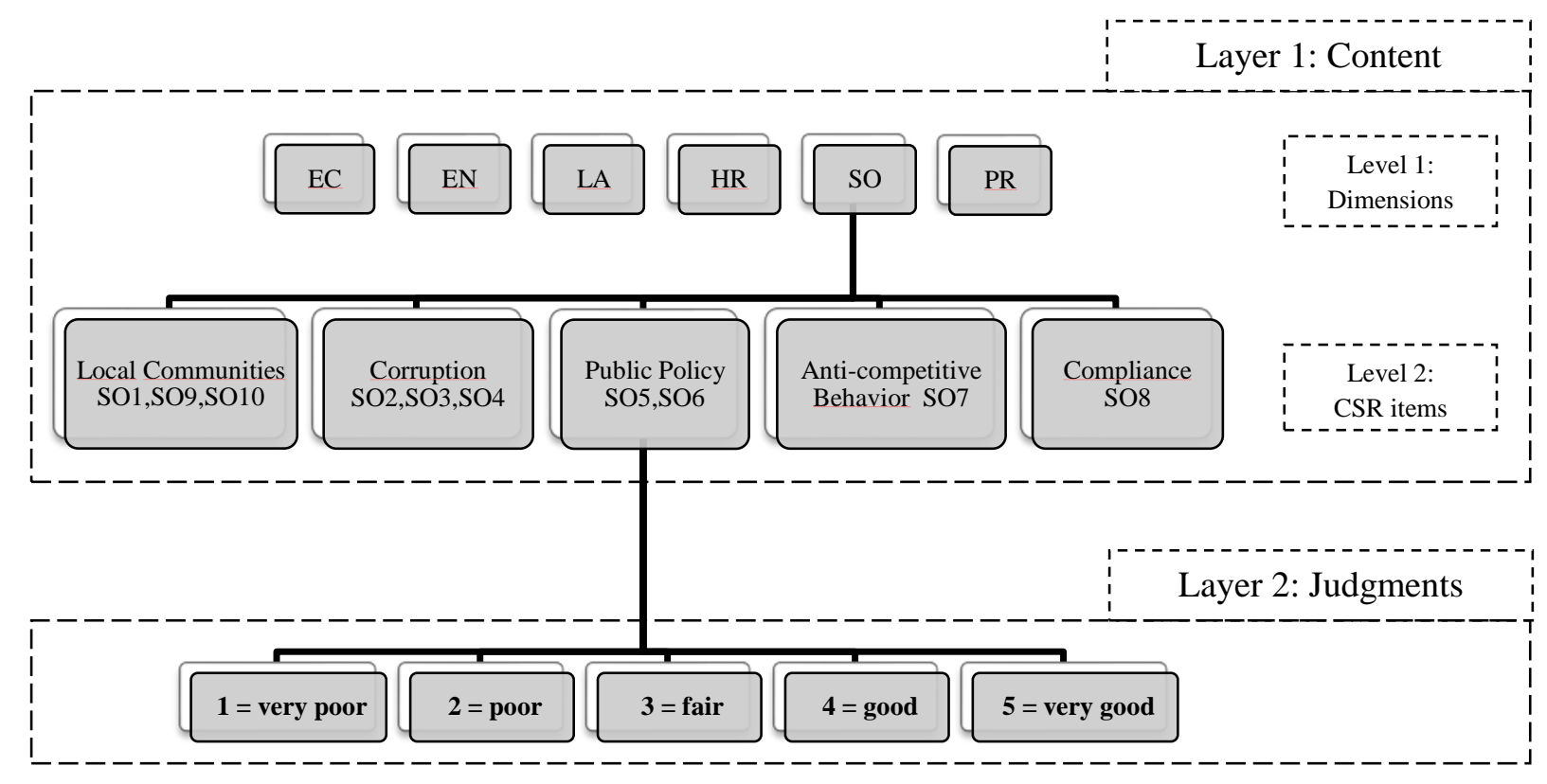

Figure 2: The coding structure of content analysis 


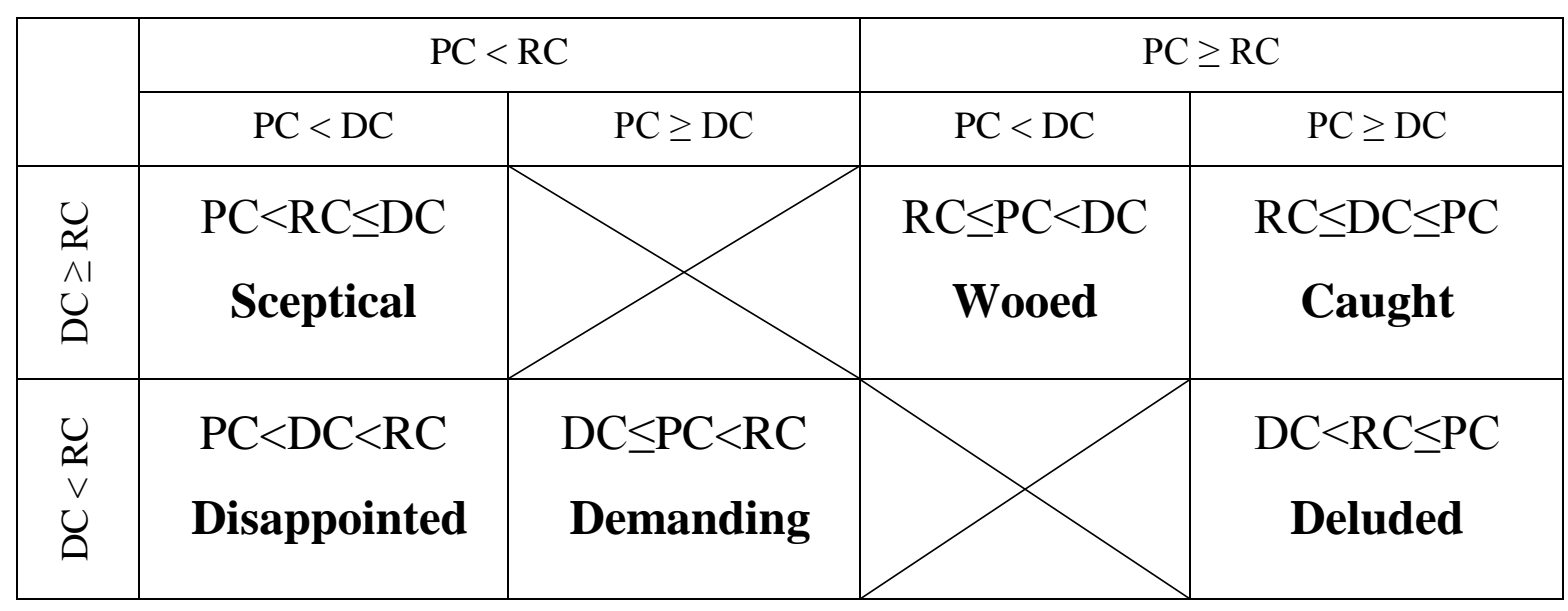

Figure 3: The CSR Customer Matrix based on the comparison among company disclosed commitment (DC), customer required commitment (RC) and customer perceived commitment (PC) 


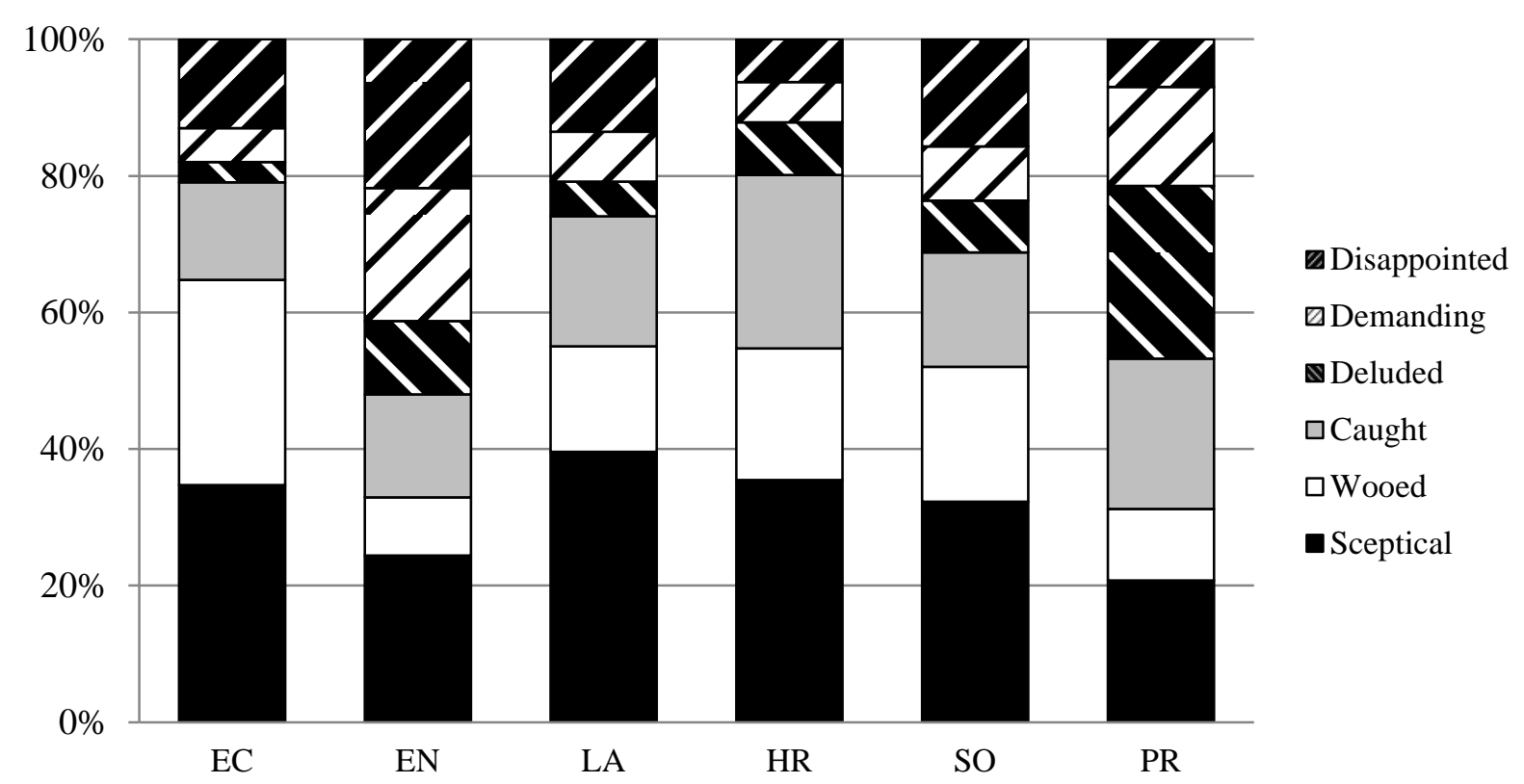

Figure 4: Customer judgments by CSR dimensions 


\section{PR}

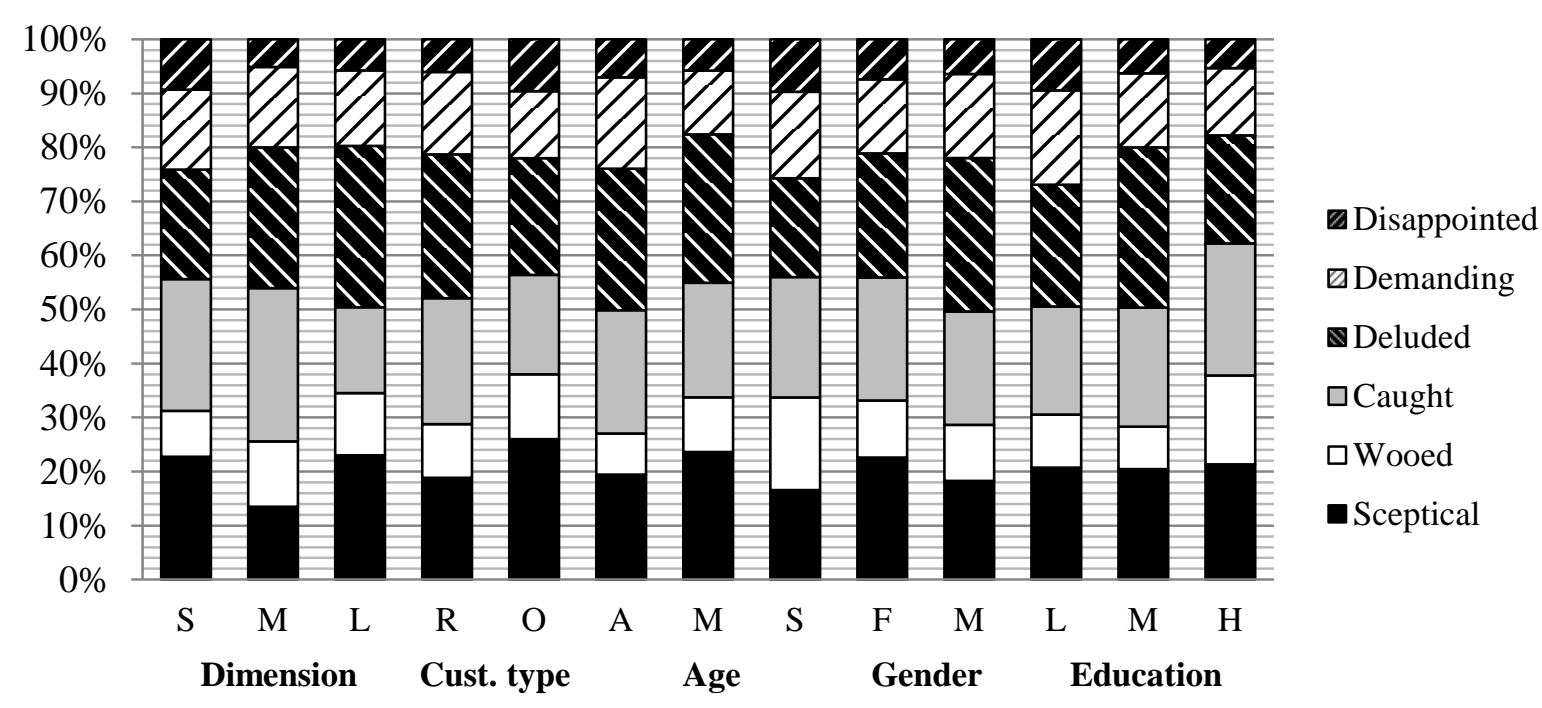

Figure 5: Customer judgments for PR social sub-dimension*

*Dimension (Retail Store Dimension: $S=$ small; $M=$ medium; $L=$ large), Customer type $(R=$ regular; $O=$ occasional), Age (A, adult = "20-40”; $M$, middle aged = "40-60”; , senior = “>60"), Gender ( $F=$ female; $M=$ male), Education $(L=$ low; $M=$ medium; $H$ = high). 


\section{PR1+PR2}

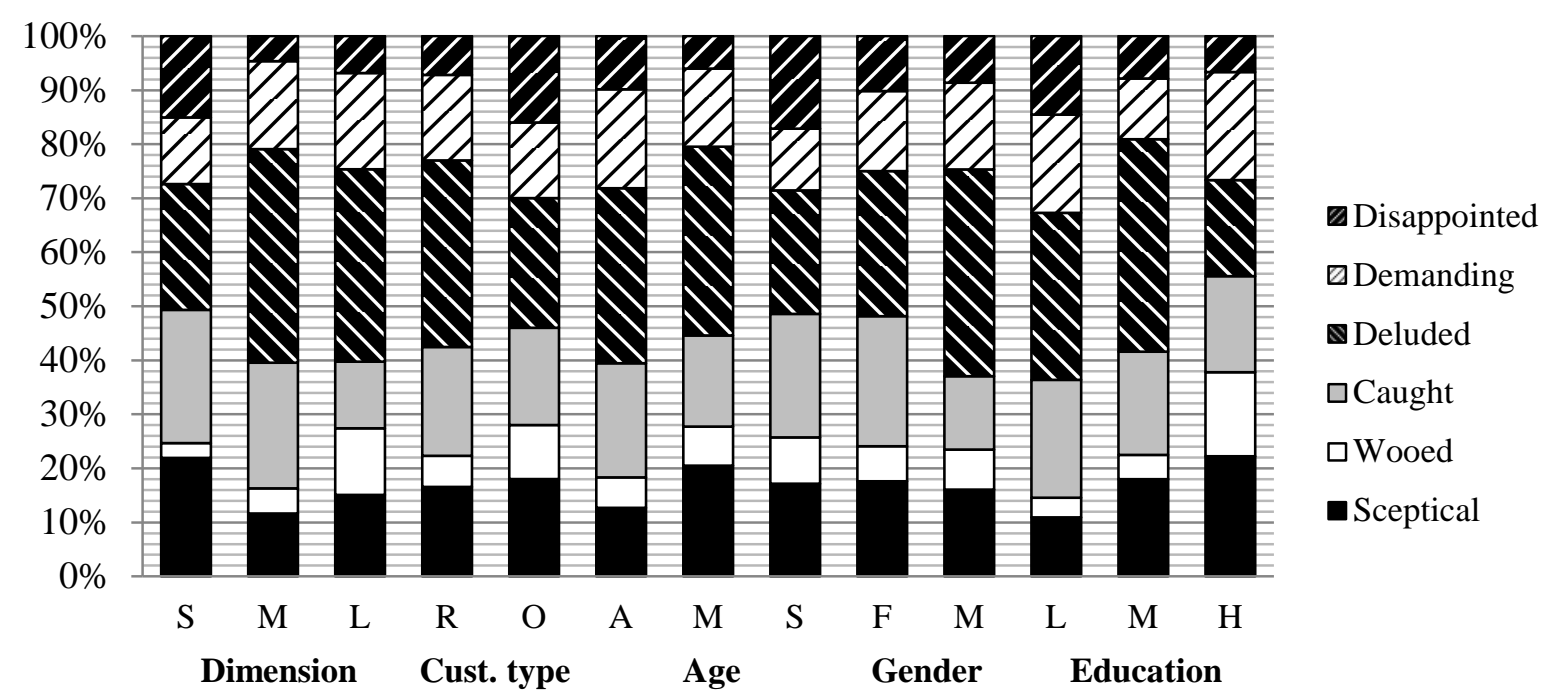

Figure 6: Customer judgments for PR1+PR2 CSR item (Customer Health and Safety)*

*Dimension (Retail Store Dimension: $S=$ small; $M=$ medium; $L=$ large), Customer type $(R=$ regular; $O=$ occasional), Age (A, adult = "20-40”; $M$, middle aged = “40-60”; , senior = “>60”), Gender ( F = female; $M=$ male), Education $(L=$ low; $M$ = medium; $H$ = high). 


\section{Tables}

\begin{tabular}{|c|c|c|}
\hline CSR dimension & CSR sub-dimension & CSR items \\
\hline Economic & ( & $\begin{array}{l}\text { Direct economic value (EC1) } \\
\text { Financial implications due to climate change (EC2) } \\
\text { Organization’s benefit plan obligations (EC3) } \\
\text { Financial assistance received from a government (EC4) } \\
\text { Market presence (EC5+EC6+EC7) } \\
\text { Indirect Economic Impacts (EC8+EC9) }\end{array}$ \\
\hline Environmental & - & $\begin{array}{l}\text { Materials (EN1+EN2) } \\
\text { Energy (EN3+EN4+EN5+EN6+EN7) } \\
\text { Water (EN8+EN9+EN10) } \\
\text { Biodiversity (EN11+EN12+EN13+EN14+EN15) } \\
\text { Emissions (EN16+EN17+EN18+EN19+EN20) } \\
\text { Effluents and spills (EN21+EN23+EN25) } \\
\text { Waste(EN22+EN24) } \\
\text { Products and Services (EN26+EN27) } \\
\text { Compliance with environmental laws and regulations (EN28) } \\
\text { Transport (EN29) } \\
\text { Overall (EN30) }\end{array}$ \\
\hline \multirow{4}{*}{ Social } & $\begin{array}{l}\text { Labor Practices and } \\
\text { Decent Work (LA) }\end{array}$ & $\begin{array}{l}\text { Employment (LA1+LA2+LA3+LA15) } \\
\text { Labor/Management Relations (LA4+LA5) } \\
\text { Occupational Health and Safety (LA6+LA7+LA8+LA9) } \\
\text { Training and Education (LA10+LA11+LA12) } \\
\text { Diversity and Equal Opportunity (LA13+LA14) }\end{array}$ \\
\hline & Human Rights (HR) & $\begin{array}{l}\text { Investment and Procurement Practices (HR1+HR2+HR3) } \\
\text { Non-discrimination (HR4) } \\
\text { Freedom of Association and Collective Bargaining (HR5) } \\
\text { Child Labor (HR6) } \\
\text { Forced and Compulsory Labor (HR7) } \\
\text { Security Practices (HR8) } \\
\text { Indigenous Rights (HR9) } \\
\text { Remediation (HR10) } \\
\text { Assessment (HR11) }\end{array}$ \\
\hline & Society (SO) & $\begin{array}{l}\text { Local Communities (SO1+SO9+SO10) } \\
\text { Corruption (SO2+SO3+SO4) } \\
\text { Public Policy (SO5+SO6) } \\
\text { Anti-Competitive Behavior (SO7) } \\
\text { Compliance with laws and regulations related to accounting } \\
\text { fraud, workplace discrimination and corruption (SO8) }\end{array}$ \\
\hline & $\begin{array}{c}\text { Product } \\
\text { Responsibility (PR) }\end{array}$ & $\begin{array}{l}\text { Customer Health and Safety (PR1+PR2) } \\
\text { Product and Service Labeling (PR3+PR4+PR5) } \\
\text { Marketing Communications (PR6+PR7) } \\
\text { Customer Privacy (PR8) } \\
\text { Compliance with laws and regulations concerning provision } \\
\text { and use of products and services (PR9) }\end{array}$ \\
\hline
\end{tabular}

Table 1: GRI structured framework: CSR dimensions, sub-dimensions and items. 
This is the accepted version of the research article: Calabrese, A., Costa, R., \& Rosati, F. (2015). A feedback-based model for CSR assessment and materiality analysis. Accounting Forum, 39(4), 312-327. Available in final form at: http://www.sciencedirect.com/science/article/pii/S0155998215000265

\begin{tabular}{c|c|c|c|c|c|c|c|c|c}
\hline \multicolumn{3}{c|}{ Cust. type (\%) } & \multicolumn{3}{|c|}{ Age (\%) } & \multicolumn{3}{c|}{ Gender (\%) } & \multicolumn{3}{c}{ Education (\%) } \\
\hline R & O & A & M & S & F & M & L & M & H \\
\hline 73.5 & 26.5 & 37.6 & 43.9 & 18.5 & 57.1 & 42.9 & 29.1 & 47.1 & 23.8 \\
\hline
\end{tabular}

Table 2: Customer sample characteristics*

*Customer type ( $R=$ regular; $O=$ occasional), Age (A, adult = “20-40”; $M$, middle aged = "40-60”; S, senior = “>60”), Gender ( $F=$ female; $M=$ male), Education ( $L=$ low; $M=$ medium; $H=$ high $)$. 


\begin{tabular}{|c|c|c|c|c|c|c|c|c|c|c|c|c|c|}
\hline & & & & C & & & & C & & & & $\mathrm{C}$ & \\
\hline & CSR item & Avg & Med & Mode & S.D. & Avg & Med & Mode & S.D. & Avg & Med & Mode & S.D. \\
\hline & 1 & 4 & 4 & 4 & 0 & 3.74 & 4 & 4 & 0.96 & 3.34 & 3 & 3 & 0.79 \\
\hline & 2 & 4 & 4 & 4 & 0 & 3.67 & 4 & 4 & 0.96 & 3.16 & 3 & 3 & 0.82 \\
\hline & 3 & 4 & 4 & 4 & 0 & 3.93 & 4 & 4 & 0.94 & 3.17 & 3 & 3 & 0.82 \\
\hline 되 & $5,6,7$ & 5 & 5 & 5 & 0 & 4.02 & 4 & 4 & 0.90 & 3.34 & 3 & 3 & 0.82 \\
\hline & 8,9 & 4.75 & 5 & 5 & 0.5 & 3.88 & 4 & 4 & 0.95 & 3.11 & 3 & 3 & 0.92 \\
\hline & Total EC & 4.35 & 4 & 4 & 0.49 & 3.85 & 4 & 4 & 0.95 & 3.22 & 3 & 3 & 0.84 \\
\hline & 1,2 & 4 & 4 & 4 & 0 & 4.41 & 5 & 5 & 0.71 & 3.62 & 4 & 3 & 0.86 \\
\hline & $3,4,5,6,7$ & 5 & 5 & 5 & 0 & 4.43 & 5 & 5 & 0.69 & 3.41 & 3 & 3 & 0.93 \\
\hline & $8,9,10$ & 3 & 3 & 3 & 0 & 4.47 & 5 & 5 & 0.72 & 3.33 & 3 & 3 & 0.83 \\
\hline & $11,12,13,14,15$ & 4 & 4 & 4 & 0 & 4.33 & 5 & 5 & 0.79 & 3.38 & 3 & 3 & 0.83 \\
\hline & $16,17,18,19,20$ & 4.25 & 4 & 5 & 0.5 & 4.48 & 5 & 5 & 0.70 & 3.32 & 3 & 3 & 0.83 \\
\hline$z_{1}$ & 22,24 & 4 & 4 & 4 & 0 & 4.60 & 5 & 5 & 0.66 & 3.52 & 4 & 4 & 0.88 \\
\hline & 26,27 & 4 & 4 & 4 & 0 & 4.34 & 4 & 5 & 0.75 & 3.52 & 4 & 4 & 0.94 \\
\hline & 28 & 4 & 4 & 4 & 0 & 4.45 & 5 & 5 & 0.70 & 3.68 & 4 & 4 & 0.87 \\
\hline & 29 & 4 & 4 & 4 & 0 & 4.24 & 4 & 5 & 0.81 & 3.32 & 3 & 3 & 0.90 \\
\hline & 30 & 4 & 4 & 4 & 0 & 4.32 & 5 & 5 & 0.81 & 3.46 & 3 & 3 & 0.90 \\
\hline & Total EN & 4.08 & 4 & 4 & 0.53 & 4.41 & 5 & 5 & 0.74 & 3.46 & 3 & 3 & 0.89 \\
\hline & $1,2,3,15$ & 5 & 5 & 5 & 0 & 4.35 & 4 & 5 & 0.73 & 3.45 & 3 & 3 & 0.86 \\
\hline & 4,5 & 4 & 4 & 4 & 0 & 4.20 & 4 & 5 & 0.86 & 3.26 & 3 & 3 & 0.81 \\
\hline$\varangle$ & $6,7,8,9$ & 5 & 5 & 5 & 0 & 4.51 & 5 & 5 & 0.70 & 3.68 & 4 & 4 & 0.92 \\
\hline 1 & $10,11,12$ & 4 & 4 & 4 & 0 & 4.10 & 4 & 4 & 0.79 & 3.35 & 3 & 3 & 0.84 \\
\hline & 13,14 & 4 & 4 & 4 & 0 & 4.37 & 5 & 5 & 0.75 & 3.59 & 4 & 3 & 0.92 \\
\hline & Total LA & 4.40 & 4 & 4 & 0.50 & 4.31 & 4 & 5 & 0.78 & 3.47 & 3 & 3 & 0.88 \\
\hline & $1,2,3$ & 5 & 5 & 5 & 0 & 4.08 & 4 & 4 & 0.88 & 3.20 & 3 & 3 & 0.86 \\
\hline & 4 & 4 & 4 & 4 & 0 & 4.39 & 5 & 5 & 0.72 & 3.79 & 4 & 3 & 0.93 \\
\hline & 6 & 5 & 5 & 5 & 0 & 4.53 & 5 & 5 & 0.73 & 4.12 & 4 & 5 & 0.86 \\
\hline$\simeq$ & 7 & 5 & 5 & 5 & 0 & 4.56 & 5 & 5 & 0.66 & 4.08 & 4 & 5 & 0.90 \\
\hline I & 9 & 5 & 5 & 5 & 0 & 4.36 & 5 & 5 & 0.77 & 3.86 & 4 & 3 & 0.96 \\
\hline & 10 & 4 & 4 & 4 & 0 & 4.20 & 4 & 5 & 0.86 & 3.59 & 3 & 3 & 0.89 \\
\hline & 11 & 4 & 4 & 4 & 0 & 4.19 & 4 & 5 & 0.81 & 3.49 & 3 & 3 & 0.85 \\
\hline & Total HR & 4.57 & 5 & 5 & 0.50 & 4.33 & 5 & 5 & 0.79 & 3.73 & 4 & 3 & 0.94 \\
\hline & $1,9,10$ & 5 & 5 & 5 & 0 & 4.13 & 4 & 4 & 0.86 & 3.40 & 3 & 3 & 0.85 \\
\hline 0 & $2,3,4$ & 4 & 4 & 4 & 0 & 4.17 & 4 & 5 & 0.85 & 3.26 & 3 & 3 & 0.84 \\
\hline$\omega$ & 8 & 4 & 4 & 4 & 0 & 4.32 & 5 & 5 & 0.79 & 3.63 & 4 & 3 & 0.86 \\
\hline & Total SO & 4.33 & 4 & 4 & 0.49 & 4.21 & 4 & 5 & 0.84 & 3.43 & 3 & 3 & 0.86 \\
\hline & 1,2 & 4 & 4 & 4 & 0 & 4.44 & 5 & 5 & 0.74 & 3.93 & 4 & 5 & 0.97 \\
\hline & $3,4,5$ & 4 & 4 & 4 & 0 & 4.44 & 5 & 5 & 0.71 & 3.77 & 4 & 4 & 1.03 \\
\hline 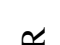 & 6,7 & 4 & 4 & 4 & 0 & 4.18 & 4 & 5 & 0.89 & 3.86 & 4 & 5 & 0.97 \\
\hline $\bar{a}$ & 8 & 3 & 3 & 3 & 0 & 4.19 & 4 & 5 & 0.92 & 3.84 & 4 & 4 & 0.92 \\
\hline & 9 & 5 & 5 & 5 & 0 & 4.28 & 4 & 5 & 0.82 & 3.70 & 4 & 4 & 0.93 \\
\hline & Total PR & 4.00 & 4 & 4 & 0.65 & 4.31 & 5 & 5 & 0.83 & 3.82 & 4 & 4 & 0.97 \\
\hline & Total items & 4.27 & 4 & 4 & 0.56 & 4.27 & 4 & 5 & 0.83 & 3.53 & 3 & 3 & 0.92 \\
\hline
\end{tabular}

Table 3: Descriptive statistics*

* Avg = Average; Med = Median; S.D. = Standard Deviation. 